\title{
The effect of ADD-H preservative (ammonium propi- onate) on the molding of baled hay
}

\author{
MARJUT KOTIMAA ${ }^{1}$, MIRJA MUSTONEN ${ }^{2}$ and KAJ HUSMAN ${ }^{1}$ \\ ${ }^{1}$ Kuopio Regional Institute of Occupational Health, P.O.B. 261, SF-70101 \\ Kuopio 10, Finland \\ ${ }^{2}$ Valio, Finnish Co-operative Dairies' Association/University of Kuopio, \\ P.O.B. 6, SF-70211 Kuopio 21, Finland
}

\begin{abstract}
The quality and the quantity of spore dust liberated from bales of hay treated with different doses of ammonium propionate (ADD-H) were studied during one indoor foddering period. The quantity of both mesophilic mold spores (especially Aspergillus umbrosus) and of thermophilic actinomycetes liberated from bales not treated with ADD-H was statistically significantly greater than the amount liberated from treated bales. There were no statistically significant differences in the amount of spores liberated from the bales treated with different doses of ADD-H.
\end{abstract}

\section{Introduction}

Farmers on dairy farms are exposed to both organic and inorganic dusts. The mold, the actinomycete spores, and the parts of fungal mycelium found in organic dusts may cause allergic alveolitis (PEPYS and JENKINS 1965). Within farming populations, allergic alveolitis is called farmer's lung disease (FLD) (PARKES 1974).

Certain thermophilic actinomycetes have been thought to cause FLD (PEPYS and JENKINS 1965), but some molds may also cause the disease (TERHO 1978).

According to Katila (1979) about $4 \%$ of the dairy farmers in Northern Savolax (a region of Finland) suffer from symptoms resembling those of FLD. NYGARD et al (1980) reported that similar symptoms are experienced by $2 \%$ of all finnish farmers. Each year 250-400 new cases of FLD are estimated to occur in Finland. According to the occupational disease register in 1979 fungi or molds caused 170 occupational diseases. Of these cases 163 were cases of allergic alveolitis, 144 of them within agriculture (VAARANEN and VASAMA 1980).

Mold and actinomycete spores are liberated from moldy material; in agriculture the most common sources are moldy hay, straw, or grain. A 
farmer is exposed to the greatest number of spores when he handles moldy material (KOTIMAA et al. 1978). Concerning molding the most critical environmental factor is the water content. If the weight of the hay contains more than $16 \%$ (GREGORY et al. 1963 a)) or more than $20 \%$ (CHARLICK et al. 1980) of water, the hay can begin to mold.

The aim of the present study was to examine how the treatment of hay with ammonium propinate (ADD-H) influences a farmer's exposure to spore dust during the indoor foddering period.

\section{Material and methods}

The study was carried out on a farm on Southern Finland. The hay was baled and treated with bisammoniumpropionate (ADD-H) on the farm. Four levels of ADD-H were used to treat the hay (Table 1).

Samplings for determining the exposure to spore dust were taken just after baling and seven times during the indoor foddering period. The first samples were taken in July, 1979 and the last ones in May, 1980.

Samples for the determination of molds and actinomycetes were taken as air samples of farmer's breathing zone during the handling of hay. A 6-stage Andersen sampler (model 10-800, Andersen 2000 inc., Georgia, USA) was used for sampling (ANDERSEN 1958). In the Andersen sampler, the spores present in the sampled air are impacted on the surface of a medium contained

Table 1. Doses of ADD-H used on the farm. The amount of acid is expressed as kilograms (kg) per ton (tn) hay.

\begin{tabular}{lcc}
\hline Bale code & $\begin{array}{c}\text { The amount of ADD-H } \\
(\mathrm{kg} / \mathrm{tn})\end{array}$ & $\begin{array}{c}\text { The water content of the hay } \\
\text { during baling }(\%)\end{array}$ \\
\hline C I & 13,5 & 21,1 \\
C II & 8,2 & 20,7 \\
C III & 7,9 & 24,0 \\
C IV & 0,0 & 14,1 \\
\hline
\end{tabular}

Table 2. The culture media and incubation temperatures and incubation times used in the Andersen samplings.

\begin{tabular}{llll}
\hline $\begin{array}{l}\text { Micro-organism or } \\
\text { group studied }\end{array}$ & Medium & $\begin{array}{l}\text { Incubation } \\
\text { temperature } \\
\left({ }^{\circ} \mathrm{C}\right)\end{array}$ & $\begin{array}{l}\text { Duration of } \\
\text { incubation } \\
\text { (days) }\end{array}$ \\
\hline $\begin{array}{l}\text { Mesophilic molds } \\
\text { Aspergillus umbrosus }\end{array}$ & $\begin{array}{l}\text { Hagen (Russel 1974) } \\
\text { Medium of sodium chloride } \\
\text { and malt extract }\end{array}$ & $\begin{array}{l}20 \pm 2 \\
20 \pm 2\end{array}$ & $7-10$ \\
$\begin{array}{l}\text { Thermotolerant molds } \\
\text { Thermophilic actino- }\end{array}$ & $\begin{array}{l}\text { Hagen } \\
\text { mycetrength Nutrient }\end{array}$ & $40 \pm 3$ & $4-5$ \\
\hline
\end{tabular}


in Petri dishes. After the sampling the Petri dishes were incubated, and the colonies which developed during the incubation period were then counted and analyzed (Table 2).

Two statistical methods were used to analyze the data. The Wilcoxon test was applied so that fluctuations in the concentrations of spores during the indoor foddering period could be studied. Multiple regression analysis was used so that the effects of various factors (time; the dose of ADD-H; the ambient temperature; and the water content of the hay) on the concentrations of spores could be analyzed.

\section{Results}

The total concentration of spores measured in the air during the handling of hay reveals the level of exposure to spore dust. The total concentration of spores for each sampling is presented in fig. 1. The total spore count was significantly greater during the handling of non-treated bales (C IV) than the handling of treated bales (C I, p $<0,05 ; \mathrm{C} \mathrm{II}, \mathrm{p}<0,01 ; \mathrm{C} \mathrm{III,} \mathrm{p}<0,005$ using the Wilcoxon test).

When the above-mentioned media and incubation temperatures are used, the total amount of spores is a function of mesophilic and thermotolerant molds and thermophilic actinomycete spores. Therefore the amount of these groups of spores for each sampling is presented in figs. 2, 3, 4, and 5.

The amount of mesophilic mold spores was statistically significantly greater in non-treated bales than in treated bales $(\mathrm{p}<0,05, \mathrm{p}<0,005, \mathrm{p}<$ $0,005)$. There were no statistically significant differences in the occurrence of thermotolerant molds. Thermophilic actinomycete spores were statistically significantly more abundant in non-treated bales than in the bales of group C III $(p<0,01)$. But when compared with other groups of bales (C I and C II), the differences were not statistically significant. Of individual species the spores of Thermoactinomyces vulgaris and Micropolyspora faeni (included in thermophilic actinomycetes) were more abundant in non-treated bales than in the bales of group C III $(p<0,025$ and $p<0,05)$. There was no difference in the number of spores of Aspergillus fumigatus (included in the thermotolerant molds) between the bales of different groups. The amount of Aspergillus umbrosus spores was significantly greater in non-treated bales than in bales treated with ADD-H $(\mathrm{p}<0,05)$.

Table 3. presents which mold or actinomycete species or genera were found and to what extent when the bales of groups C I, C II, C III, and C IV were handled.

We used multiple regression analysis to examine the effects of the ambient temperature, the duration of storage, water content of the hay and ADD-Hdose on different spore variables. The results are presented in Table 4. The fitness of the model was $41-66 \%$ depending on the spore variable concerned. 


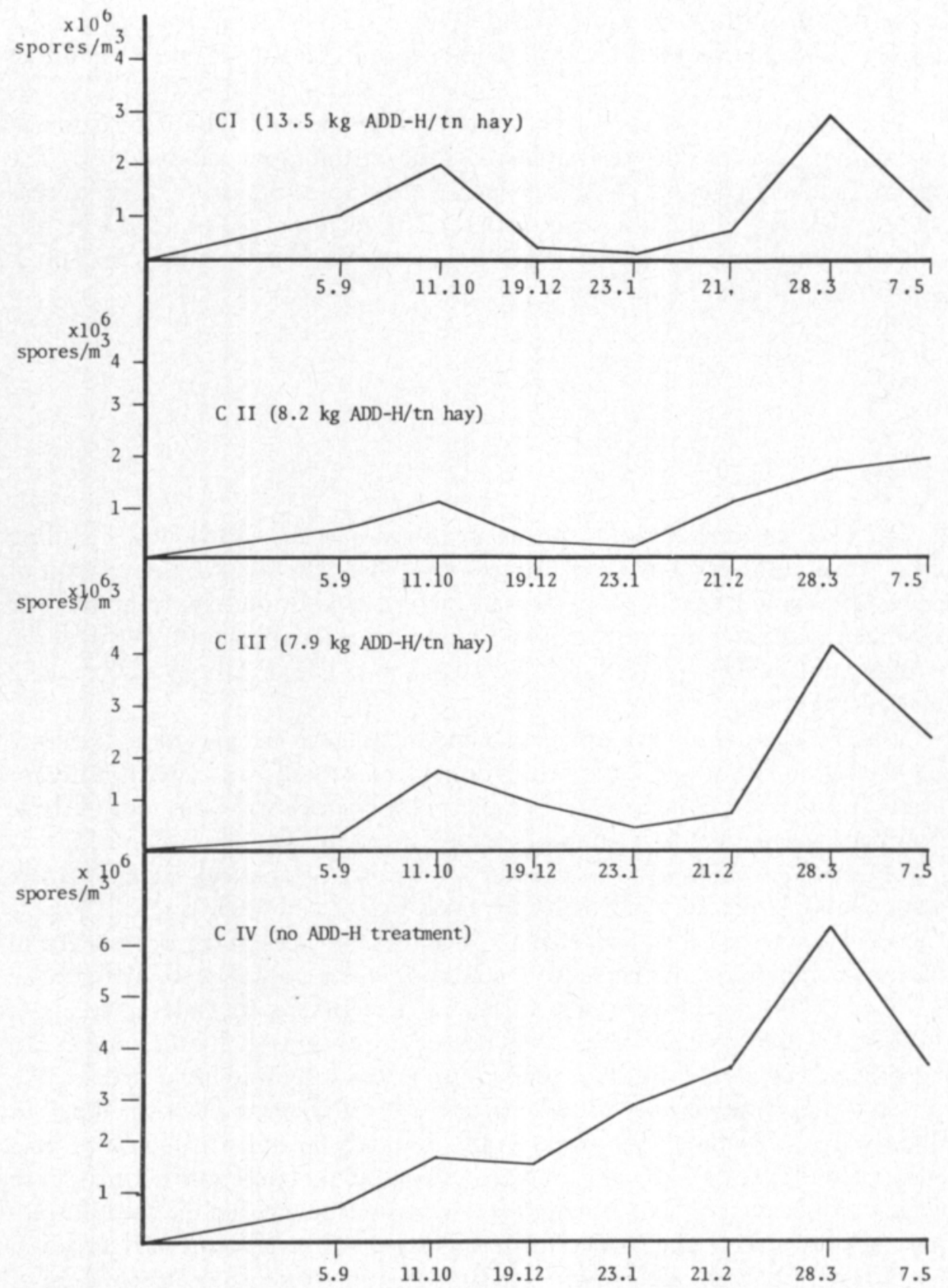

Fig. 1. The total concentration of spores when baled hay treated with different doses of ADD-H was handled. 


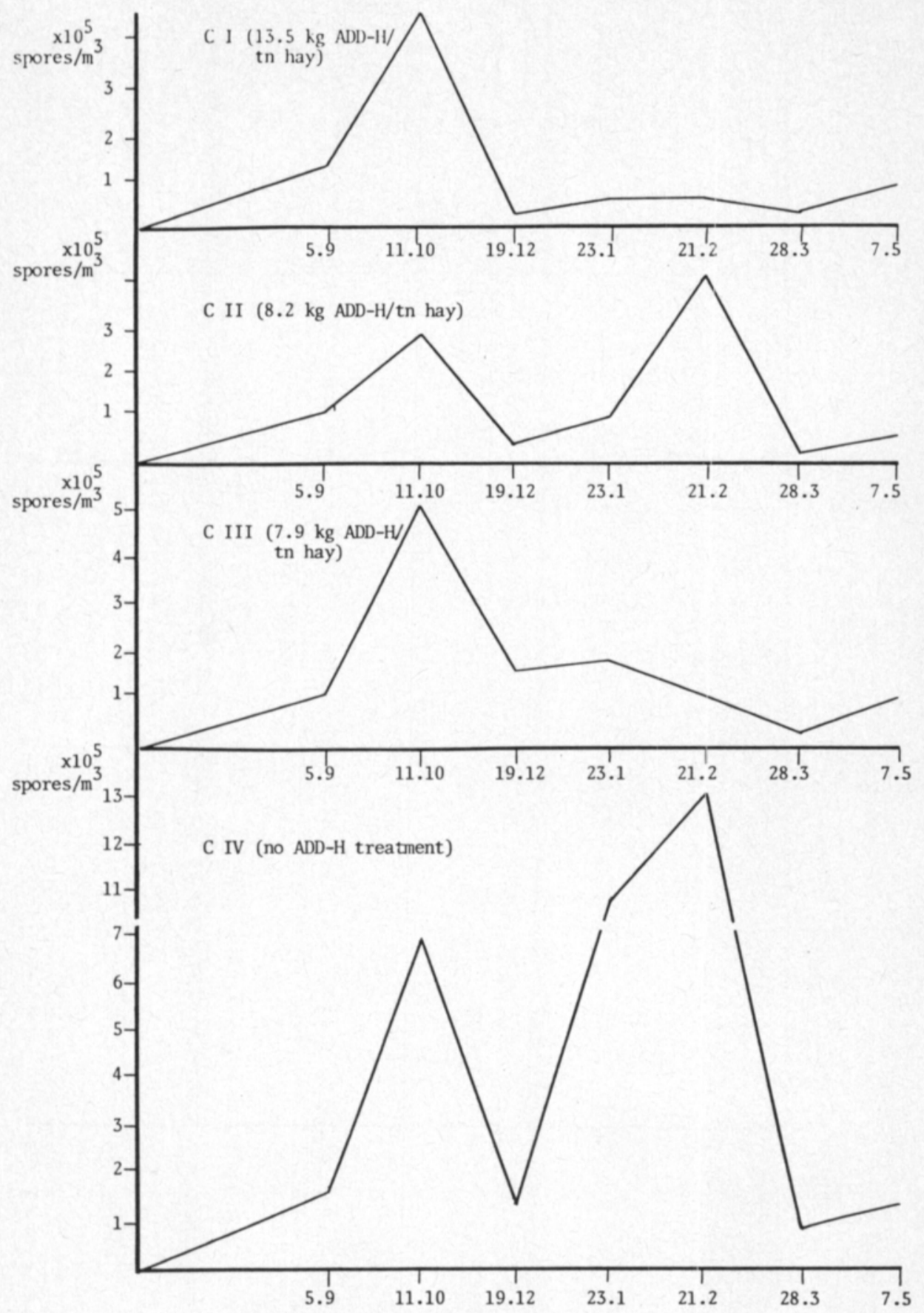

Fig. 2. The concentration of mesophilic mold spores (not A. umbrosus) when baled hay treated with different doses of ADD-H was handled. 


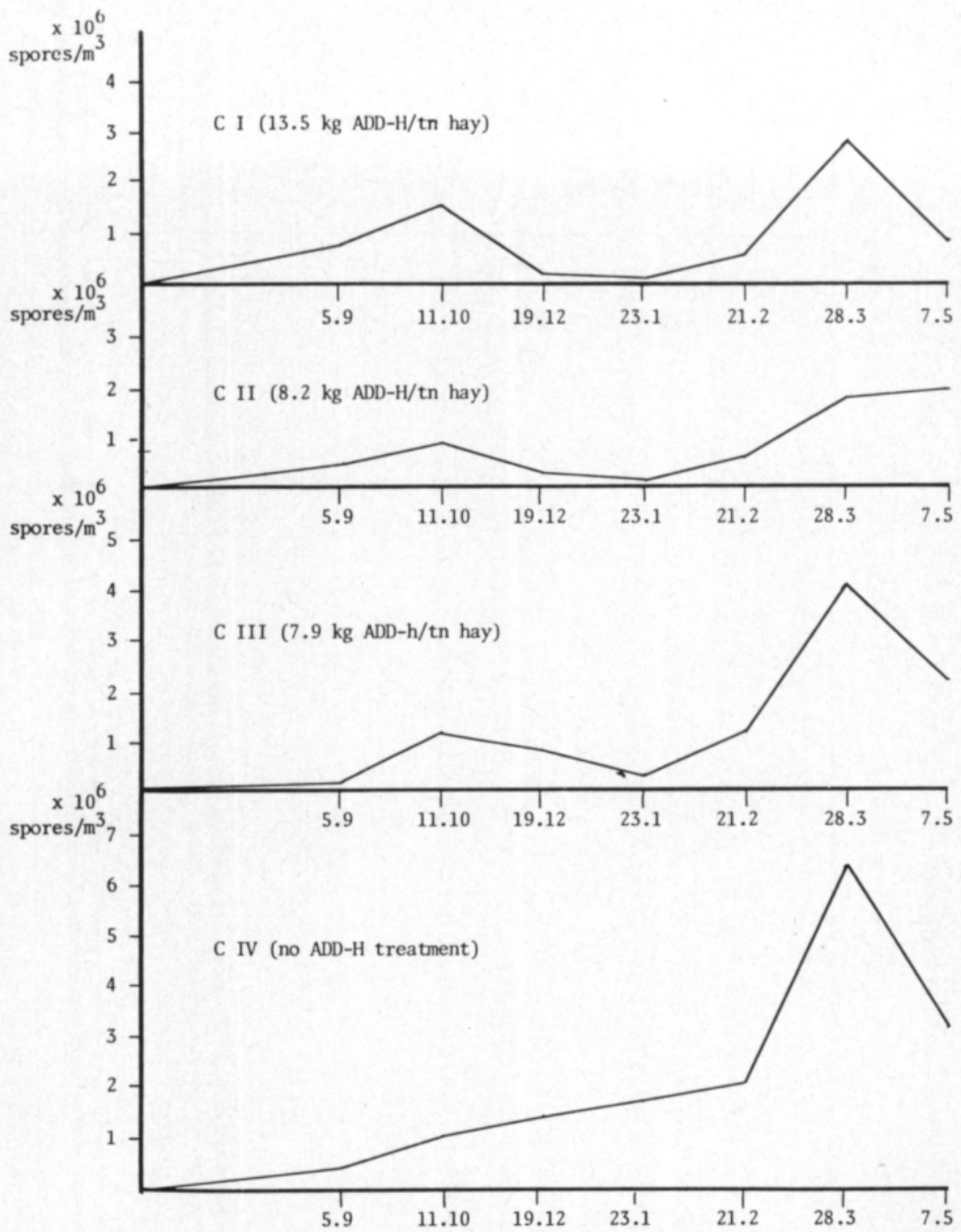

Fig. 3. The concentration of $A$. umbrosus spores when baled hay treated with different doses of ADD-H was handled. 


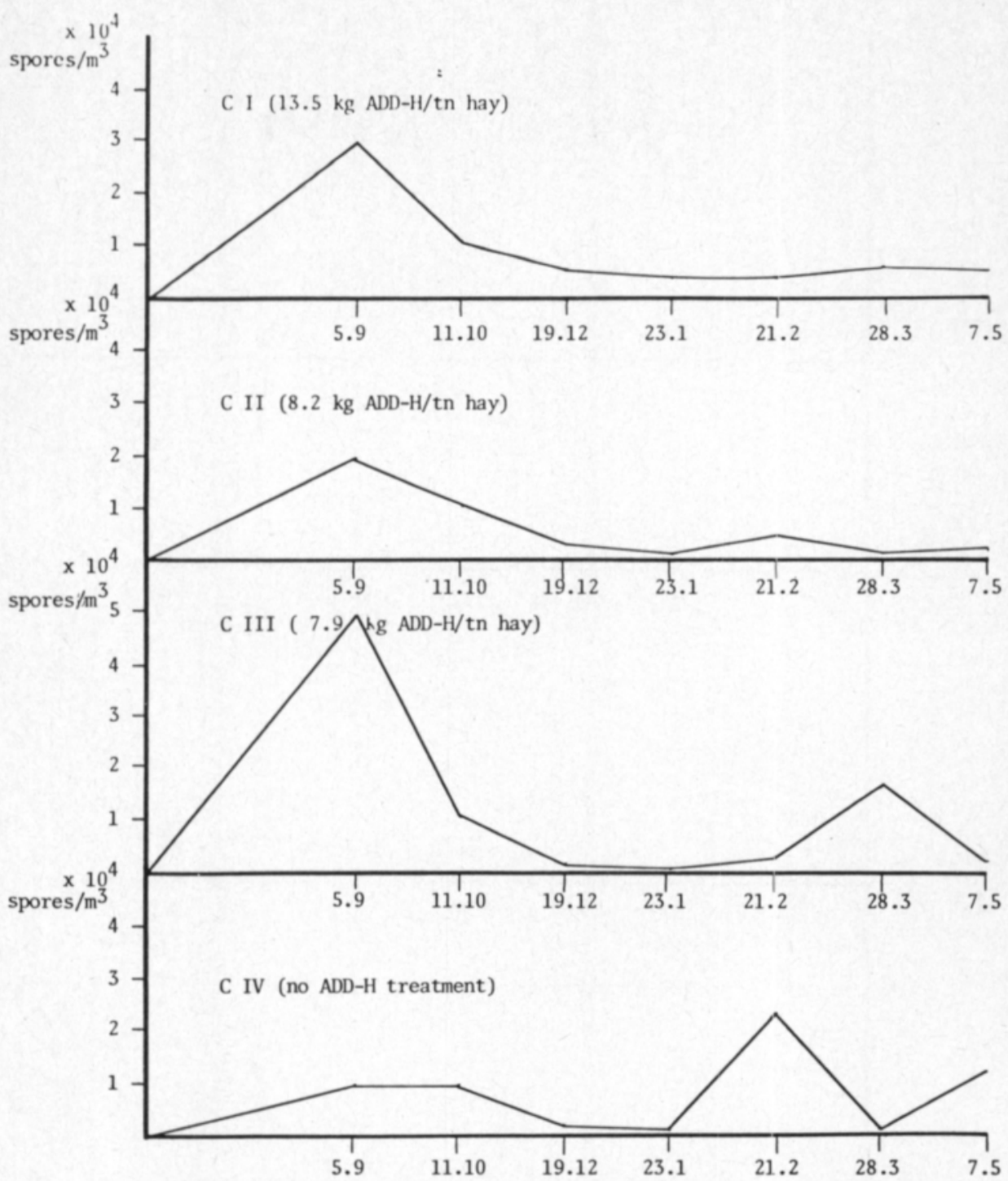

Fig. 4. The concentration of thermotolerant mold spores when baled hay treated with different doses of ADD-H was handled. 


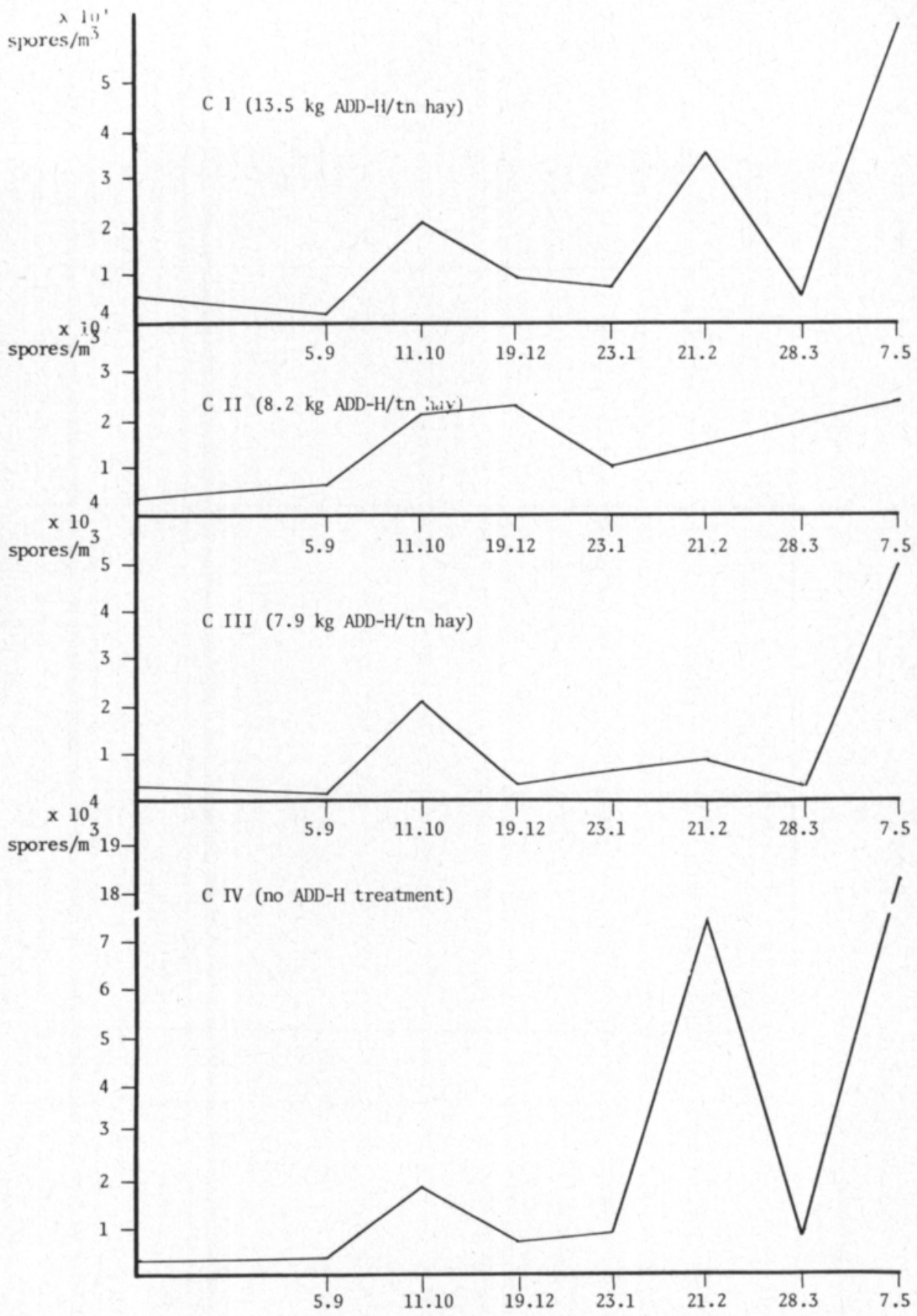

Fig. 5. The concentration of thermophilic actinomycete spores when baled hay treated with different doses of ADD-H was handled. 
Table 3. Fungi and actinomycetes found in the studied samples of hay. The mean concentration of each species or genus during the indoor foddering period is presented by $+-\operatorname{sign} .\left(-=0\right.$ spores $/ \mathrm{m}^{3},+$ $=1-5000$ spores $/ \mathrm{m}^{3},++=5001-50000$ spores $/ \mathrm{m}^{3},+++=50001-500000$ spores $/ \mathrm{m}^{3},++++$ $=>500000$ spores $/ \mathrm{m}^{3}$ )

\begin{tabular}{|c|c|c|c|c|}
\hline & C I & C II & C III & C IV \\
\hline Thermoactinomyces vulgaris & ++ & ++ & ++ & ++ \\
\hline Micropolyspora faeni & ++ & + & + & ++ \\
\hline other thermophilic actinomycetes & + & + & + & + \\
\hline Aspergillus fumigatus & + & + & + & + \\
\hline A. niger & + & + & ++ & + \\
\hline Aspergillus sp. & + & + & + & + \\
\hline Mucor sp. & + & + & + & + \\
\hline Rhizopus sp. & - & - & + & - \\
\hline Paecilomyces sp. & + & + & + & + \\
\hline yeasts & + & + & + & + \\
\hline other thermotolerant molds & + & + & + & + \\
\hline Aspergillus umbrosus & ++++ & ++++ & ++++ & ++++ \\
\hline Aspergillus sp. & +++ & +++ & +++ & +++ \\
\hline Alternaria sp. & + & + & + & + \\
\hline Aureobasidium sp. & + & + & + & + \\
\hline Botrytis sp. & + & + & + & + \\
\hline Cladosporium sp. & + & + & ++ & ++ \\
\hline Geotrichum sp. & - & + & + & - \\
\hline Mucor sp. & + & + & + & + \\
\hline Penicillium sp. & ++ & ++ & ++ & ++ \\
\hline Paecilomyces sp. & - & + & - & + \\
\hline Rhizopus sp. & + & + & + & + \\
\hline Thysanophora sp. & + & + & - & - \\
\hline Trichoderma sp. & + & - & + & + \\
\hline Trichophyton sp. & + & - & + & + \\
\hline yeasts & + & + & + & + \\
\hline other mesophilic molds & + & + & + & + \\
\hline
\end{tabular}

\section{Discussion}

There were clear changes in the total concentration of spores during the indoor foddering period in all of the bales treated with ADD-H. The first appreciable change occurred during the first three months of storage, when the total amount of spores increased from $20-40000$ spores $/ \mathrm{m}^{3}$ in July to $0,8-2,1 \mathrm{milj}$. spores $/ \mathrm{m}^{3}$ in October. The increase was greater in the bales of group C I which had been treated with the greatest dose of ADD-H. The results indicate that the ADD-H treatment would have slightly decreased the molding in all but the bales of group C I. It is possible that more acid was lost when the hay of group C I was treated; thus the effect of hindering molding was smaller than for groups C II and C III.

When the temperature of the air outdoors dropped, the amount of spores decreased. This change could be seen in all the groups of bales. When the temperature is low, the activity of molds decreases even though their growth is not completely halted (SMITH 1969). The change in the total concentration 
Table 4. The coefficients of regression for the explainable variables $(A$. umbrosus... total spore concentration) and the explaining variables (the ambient temperature ... acid/water) by multiple regression analysis.

\begin{tabular}{|c|c|c|c|c|c|c|c|}
\hline & $\begin{array}{l}\text { Asp. } \\
\text { umbr. } \\
\mathrm{x} 10^{3}\end{array}$ & $\begin{array}{l}\text { mesoph. } \\
\text { moulds } \\
\mathrm{x} 10^{3}\end{array}$ & $\begin{array}{l}\text { Asp. } \\
\text { fum. } \\
x 10^{3}\end{array}$ & $\begin{array}{l}\text { thermot. } \\
\text { moulds } \\
\text { x10 }\end{array}$ & $\begin{array}{l}\text { Tha. } \\
\text { vulg. } \\
\text { x10 }\end{array}$ & $\begin{array}{l}\text { thermop. } \\
\text { actinom. } \\
\times 10^{3}\end{array}$ & $\begin{array}{l}\text { total } \\
\text { spore conc. } \\
\times 10^{3}\end{array}$ \\
\hline temperature $\left({ }^{\circ} \mathrm{C}\right)\left(\mathrm{X}_{1}\right)$ & $\begin{array}{l}\beta_{1}=272.0 \\
F=4.94\end{array}$ & $\begin{array}{l}\beta_{1}=296.9 \\
F=8.99\end{array}$ & $\begin{array}{l}\beta_{1}=0.1 \\
F=2.17\end{array}$ & $\begin{array}{l}\beta_{1}=2.7 \\
F=2.84\end{array}$ & $\begin{array}{l}\beta_{1}=-2.3 \\
F=15.65\end{array}$ & $\begin{array}{l}\beta_{1}=-2.2 \\
F=11.24\end{array}$ & $\begin{array}{l}\beta_{1}=297.4 \\
F=9.33\end{array}$ \\
\hline time (weeks) & $\begin{array}{l}\beta_{2}=272.2 \\
F=5.30\end{array}$ & $\begin{array}{l}\beta_{2}=333.3 \\
F=13.01\end{array}$ & $\begin{array}{l}\beta_{2}=1.3 \\
F=3.25\end{array}$ & $\begin{array}{l}\beta_{2}=3.7 \\
F=4.49\end{array}$ & $\begin{array}{l}\beta_{2}=-1.7 \\
F=9.39\end{array}$ & $\begin{array}{l}\beta_{2}=-1.3 \\
F=5.98\end{array}$ & $\begin{array}{l}\beta_{2}=335.7 \\
F=13.34\end{array}$ \\
\hline temp. $\mathrm{x}$ time & $\begin{array}{l}\beta_{3}=-7.6 \\
F=4.47\end{array}$ & $\begin{array}{l}\beta_{3}=-8.1 \\
F=8.65\end{array}$ & $\begin{array}{l}\beta_{3}=-0.02 \\
F=4.11\end{array}$ & $\begin{aligned} 2 \beta_{3} & =-0.05 \\
F & =4.94\end{aligned}$ & $\begin{array}{l}\beta_{3}=0.1 \\
F=18.69\end{array}$ & $\begin{array}{l}\beta_{3}=0.1 \\
F=12.73\end{array}$ & $\begin{array}{l}\beta_{3}=-8.1 \\
F=8.85\end{array}$ \\
\hline$(\text { time })^{2}$ & $\begin{array}{l}\beta_{4}=-2.3 \\
F=15.48\end{array}$ & $\begin{array}{l}\beta_{4}=-3.4 \\
F=8.21\end{array}$ & $\begin{array}{l}\beta_{4}=-0.02 \\
F=1.56\end{array}$ & $\begin{array}{l}2 \beta_{4}=-0.06 \\
F=1.84\end{array}$ & $\begin{array}{l}\beta_{4}=0.03 \\
F=7.79\end{array}$ & $\begin{array}{l}\beta_{4}=0.03 \\
F=7.65\end{array}$ & $\begin{array}{l}\beta_{4}=-3.5 \\
F=8.41\end{array}$ \\
\hline water content $\%\left(\mathrm{X}_{5}\right)$ & $\begin{array}{l}\beta_{5}=-166.6 \\
F=8.13\end{array}$ & $\begin{array}{l}\beta_{5}=-200.4 \\
F=6.98\end{array}$ & $\begin{array}{l}\beta_{5}=-0.1 \\
F=2.33\end{array}$ & $\begin{array}{l}\beta_{5}=-0.6 \\
F=3.89\end{array}$ & $\begin{array}{l}\beta_{5}=-2.0 \\
F=12.94\end{array}$ & $\begin{array}{l}\beta_{5}=-3.9 \\
F=10.28\end{array}$ & $\begin{array}{l}\beta_{5}=-204.9 \\
F=7.17\end{array}$ \\
\hline $\begin{array}{l}\text { acid dose } \\
\text { (kg/tn hay) }\end{array}$ & $\begin{array}{l}\beta_{6}=810.0 \\
F=6.38\end{array}$ & $\begin{array}{l}\beta_{6}=908.0 \\
F=6.35\end{array}$ & $\begin{array}{l}\beta_{6}=1.2 \\
F=3.47\end{array}$ & $\begin{array}{l}\beta_{6}=6.5 \\
F=2.86\end{array}$ & $\begin{array}{l}\beta_{6}=3.6 \\
F=6.26\end{array}$ & $\begin{array}{l}\beta_{6}=9.0 \\
F=4.02\end{array}$ & $\begin{array}{l}\beta_{6}=923.6 \\
F=6.55\end{array}$ \\
\hline acid/water & $\begin{array}{l}\beta_{7}=172035.1 \\
F=12.25\end{array}$ & $\begin{array}{l}\beta_{7}=194486.4 \\
F=13.20\end{array}$ & $\begin{aligned}+\beta & =-204.2 \\
F & =2.82\end{aligned}$ & $\begin{array}{c}2 \beta_{7}=-1296.8 \\
\mathrm{~F}=3.17\end{array}$ & $\begin{array}{l}\beta \beta_{7}=-676.8 \\
F=5.19\end{array}$ & $\begin{aligned} 8 \beta_{\gamma} & =-1782.0 \\
F & =4.80\end{aligned}$ & $\begin{aligned} \beta_{7} & =197575.5 \\
F & =13.56\end{aligned}$ \\
\hline multiple $\mathrm{r}$ & 0.779 & 0.806 & 0.637 & 0.675 & 0.776 & 0.734 & 0.810 \\
\hline$r^{2}$ & 0.607 & 0.649 & 0.405 & 0.455 & 0.602 & 0.539 & 0.656 \\
\hline
\end{tabular}

of spores was greater in the treated bales than in the non-treated bales, which is propably due to the interaction of low temperature and acid treatment. The molding of group C IV bales (non-treated) continued in November and December, and the amount of spores increased until March as it had previously in our earlier study (KOTIMAA et al. 1978). The molding of bales treated with ADD-H did not begin until January or February, and it reached the peak concentration in March; group C II was an exeption, as those bales continued to mold until May.

Mesophilic molds were the most numerous of the colonies analyzed. Mesophilic molds had two peaks during the indoor foddering period. The first one, in October, was due to molding when the storage began. The other peak was in January or February, when the molds were reactivated after the cold season. The most common and abundant mesophilic molds were Aspergillus sp. Penicillium sp., Cladosporium sp. and Mucor sp., which are the molds most commonly found in moldy hay (GREGORY and LACEY 1963a, GREGORY and LACEY 1963b). In July most of studied bales liberated small quantities of both Aspergillus and Penicillium spores and large quantities of Cladosporium spores. This can be explained by the fact that Aspergillus and Penicillium are so-called storage fungi the presence of which reflects molding during storage. Cladosporium is called a field fungus; it can colonize on leaves and straw while the hay is growing (HUDSON 1972). 
Aspergillus umbrosus a mold of the A. glaucus phylum was the dominant mold. Its percentage of all the colonies during the first molding peak was $60-77 \%$, and $75-100 \%$ during the second peak. The molds of the $A$. glancus- group are typical molds which indicate the molding but not the heating of hay (GREGORY and LACEY 1963a). On the basis of the high occurence of $A$. glaucus molds, all the groups of bales studied can be characterized as moldy (GREGORY et al. 1963).

It is typical that molds of the A. glancus-group both tolerate and metabolize propionic acid (LORD and LACEY 1978). This and slight differences in the water content of the groups of bales could explain the fact that there were no clear differences in the spore composition of the groups of bales.

The number of thermotolerant molds in the bales studied was rather small. The first peak in their occurrence was in September, and the second peak occurred after the cold season in February or March. The most common thermotolerant molds were Aspergillus fumigatus and Mucor sp. When abundant, these molds indicate the heating of hay (GREGORY et al. 1963).

The amount of thermophilic actinomycetes was slightly greater than that of thermotolerant molds. Like the thermotolerant molds thermophilic actinomycetes had a two-peak distribution. The first peak occurred in October. The occurrence of thermophilic actinomycetes is usually preceeded by thermotolerant molds; thus they develop as a result of ecological succession (HUDSON 1972). The most common thermophilic actinomycete was Thermoactinomyces vulcaris. Other species (e.g., Micropolyspora faeni and Streptomyces sp.) were found more rarely. A large number of thermophilic actinomycetes indicates that heating has occurred in the hay (GREGORY et al. 1963 and CORBAZ et al. 1963).

Using multiple regression analysis we found that the ratio of acid to water has the clearest effect on the total amount of spores. The greater this ratio is, the greater the total amount of spores and the smaller the amount of both thermotolerant molds and thermophilic actinomycetes. The duration of storage and the ambient temperature also affected the molding. This is natural, as molding proceeds with time and depends on the ambient temperature.

Although the total concentration of spores in the treated bales was statistically significantly lower than the concentration in the non-treated bales, the decrease was not thought great enough to prevent FLD.

Acknowledgements. - The work was done in the Department of Environmental Hygiene at the University of Kuopio. We want to thank Prof. Lauri Kärenlampi for the critical reading of the manuscript. The technical assistance of Mrs. Mirja Korhonen is gratefully ackowledged. Financially this study was supported by the Finnish Cultural Foundation-North Savo fund, and by Valio, Finnish Co-operative Dairies' Association. 


\section{References}

ANDERSEN, A. A. (1958). New sampler for the collection, sizing and enumeration of viable airborne particles. J. Bact. 76: 471-484.

CHARLICK, R. H., HOLDEN, M. R., KLINNER, W. E. and SHEPPERSON, G. 1980. The use of preservatives in haymaking. Agric. Engin. Res. 25: 87-97.

CORBAZ, R., GREGORY, P. H. and LACEY, M. E. 1963. Thermophilic and mesophilic actinomycetes in moldy hay. J. Gen. Microbiol. 32: 449-455.

GREGORY, P. H. and LACEY, M. E. 1963 a. Mycological examination of dust from moldy hay associated with farmer's lung disease. J. Gen. Microbiol. 30: 75-88.

GREGORY, P. H. and LACEY, M. E. 1963 b. Liberation of spores from moldy hay. Trans. Brit. mycol. Soc. 46: 73-80.

GREGORY, P. H., LACEY, M. E., FESTENSTEIN, G. N. and SKINNER, F. A. 1963. Microbial and biochemical changes during the molding of hay. J. Gen. Microbiol. 33: 147-174.

HUDSON, H. J. 1972. Fungal Saprophytism. Edward Arnold Ltd., London. 67 p.

KATILA, M-L. 1979. Respiratory disease in a farming population. Acad. diss. Dept. clinical microbiol. Univ. Kuopio, Finland. 93 p.

KOTIMAA, M., TUPI, K., KÄRENLAMPI, L., TERHO, E. O., ALANKO, K. and HUSMAN, K. 1978. Exposure to biological dusts in agriculture (abstract). TTL:n tutkimuksia N:o 141. Helsinki $42 \mathrm{p}$.

LORD, K. A. and LACEY, J. 1978. Chemicals to prevent the molding of hay and other crops. J. Sci. Fd Agric. 29: 574-575.

NYGÅRD, K., JÄRVINEN E., NUUTINEN, J., TUPI, K., UKKOLA, K., HERNBERG, S., AALTO, L. 1980. Maanviljelijöiden terveydentila ja työolot. Työterveyslaitoksen tutkimuksia N:o 165114 p.

PARKERS, W. R. 1974. Occupational lung disorders. Butterworths, London.

PEPYS, J. and JENKINS, P. A. 1965. Precipitin (F.L.H.) test in farmer's lung. Thorax 20: 21-35.

RUSSEL, B. S. 1974. Mycology Guidebook. Mycology Guidebook Committee, Mycol. Soc. Amer. Univ. Wash. Press, Seattle and London.

SMITH, G. 1969. An introduction to industrial mycology (6th ed.), Edward Arnold, London. 390 p.

TERHO, E. O. 1978. Microbiological and serological studies on farmer's lung disease. Publ. Univ. Kuopio, Med. Ser. Orig. Rep. 1/1978 Kuopio.

VAARANEN, V. and VASAMA, M-R. 1980. Ammattitaudit vuonna 1979. TTL:n katsauksia N:o 34. Helsinki. 111 p.

Ms received May 18, 1983 


\section{ADD-H:n (ammoniumpropionaatin) vaikutus paalatun heinän homehtumiseen}

\section{Marjut Kotimaa $^{1}$, Mirja Mustonen ${ }^{2}$ ja Kaj Husman ${ }^{1}$}

${ }^{1}$ Kuopion aluetyöterveyslaitos, PL 261, 70101 Kuopio 10

${ }^{2}$ Valio/Kuopion yliopisto, PL 670211 Kuopio 21

ADD-H:n vaikutusta paalatun heinän homehtumiseen tutkittiin yhden sisäruokintakauden ajan määrittämällä Andersen-keräimellä heinän käsittelyn aikana ilmaan irtoavan homepölyn laatu ja määrä. Paalauksen yhteydessä käytettiin neljää eri happoannostasoa: 0.0, 7.9, 8.2 ja $13.5 \mathrm{~kg} / \mathrm{tn}$.

ADD-H-käsitellyistä paaleista irtosi sekä mesofiilisten homeiden (erityisesti Aspergillus umbrosuksen) että termofiilisten sädesienten itiöitä tilastollisesti merkitsevästi vähemmän kuin käsittelemättömistä paaleista. Sen sijaan eri annoksilla käsiteltyjen paalien välillä ei ollut tilastollisesti merkitseviä eroja, mikä selittynee osittain sillä, että happoannosten väliset erot olivat teoreettisia eroja pienemmät $\mathrm{mm}$. annostelun yhteydessä tapahtuneiden happohäviöiden vuoksi. 